Le YU

Jinhua MI

Zheng LIU

Hong-Zhong HUANG

\title{
RELIABILITY ANALYSIS OF GEAR TRANSMISSION WITH CONSIDERING FAILURE CORRELATION
}

\author{
ANALIZA NIEZAWODNOŚCI PRZEKŁADNI \\ Z UWZGLĘDNIENIEM KORELACJI USZKODZEŃ
}

\begin{abstract}
Reliability analysis is of great importance in engineering practices. However, reliability analysis of mechanical system under considering correlation for multiple failure modes is very difficult. Gear is the key component in many mechanical transmission systems and therefore its reliability analysis is very important. Based on the standards of strength calculation of gears and stressstrength interference theory as well as copula theory, the reliability of gear transmission with three failure modes, including gear bending fatigue, gear flank contact fatigue and flank adhesion, is analyzed. The correlation of the three failure modes is studied and reliability of their correlation is also evaluated based on the selected copula functions. The proposed method can be used to facilitate the design, manufacturing, and maintenance planning of gears.
\end{abstract}

Keywords: Reliability analysis; contact stress; bending stress; multiple failure modes; failure correlation.

\begin{abstract}
Analiza niezawodności ma ogromne znaczenie w praktyce inżynierskiej. Jednakże, analiza niezawodności układu mechanicznego $z$ uwzględnieniem korelacji dla mnogich przyczyn uszkodzeń jest trudnym zadaniem. Koło zębate jest kluczowym elementem $w$ wielu przekładniach mechanicznych $i$ dlatego analiza jego niezawodności jest niezwykle ważna. W oparciu o normy obliczania wytrzymatości kót zębatych i teorię interferencji naprężeń $i$ wytrzymałości, a także teorię koput, przeanalizowano niezawodność przektadni zębatej uwzględniając trzy przyczyny uszkodzeń: zmęczenie zginajace koła zębatego, zmęczenie stykowe boku zęba i przyczepność boku. Prześledzono korelację trzech przyczyn uszkodzeń i oceniono niezawodność ich korelacji na podstawie wybranych funkcji koput. Proponowana metoda może być stosowana w celu ułatwienia projektowania, produkcji i planowania konserwacji przektadni.
\end{abstract}

Stowa kluczowe: Analiza niezawodności; naprężenie stykowe; naprężenie zginające; mnogie przyczyny uszkodzeń; korelacja uszkodzeń.

\section{Introduction}

Gear is an important component of mechanical transmission. Gear transmission has been recognized as one of the most important mechanical transmission forms because it has a series of advantages, such as broad power and speed ratio in scope, high transmission efficiency, compact structure and so on. In recent years, with rapid development of machine tools, aircrafts, and automobiles, gear transmission has become an extremely important form of mechanical transmission [1, $4,6,8]$.

Reliability of mechanical transmission relies on the most critical component, e.g. gear, of the system [10]. The failure of gears in mechanical transmission will lead to a poor performance, sometimes even serious accidents and subsequently great economic loss. Therefore, developing an effective and accurate fatigue reliability evaluation model for gear transmission has been a hot topic in the gear engineering community $[2,3,11]$.

Failure modes of gears are complicated, such as teeth broken, teeth surface pitting, teeth wear, teeth bonding and teeth plastic deformations and so on, because in most cases, gears work under high speed, heavy load and strong impulse conditions. Therefore, multiple failure modes should be considered simultaneously for analyzing reliability of gears. In this paper, the gear transmission of heavy machine tools is analyzed. Tooth bending fatigue, gear contact fatigue and flank adhesion are major failure modes of heavy duty gears. The failures of weak points are dependent of each other, because all the roots (with maximum bending stress) and surfaces (with maximum contact stress) in a gear subject to the same environmental conditions. Thus, the failure dependence of a gear in the transmission system should be considered. Reliability models of gear transmission with common cause failures are developed without the assumption of failure independence $[5,6,12,14,15]$.

The paper is organized as follows. In Section 2, the strength calculation standards for gears and the copula theory as well as stressstrength interference theory are briefly introduced. Reliability calculation models are developed in Section 3. The proposed method is validated by a gear transmission of heavy machine tools with three failure modes in Section 4. Conclusions are dawn in Section 5.

\section{Reliability calculation model}

\subsection{Stress-Strength Interference (SSI) theory}

The stress-strength interference (SSI) model has been widely used for reliability analysis of mechanical components. Mathemati- 
cally, the SSI theory presents the failure probability $P_{f}$ of a mechanical system as the probability that the stress exceeds the strength. The reliability $R$ is the probability that the stress is less than the allowable strength, denoted as $[2,6]$ :

$$
R=P\left(\sigma_{a}>\sigma_{B}\right)
$$

Reliability $R$ of a component can be calculated, if the probability density functions of the allowable strength $f_{a}\left(\sigma_{a}\right)$ and the actual stress $f_{B}\left(\sigma_{B}\right)$ are known. The random variable $U$ is a measurement for the distance between the actual stress and the allowable strength:

$$
U=\sigma_{a}-\sigma_{B}
$$

$P_{R}=P(U>0)$ is the reliability; $P_{F}=P(U \leq 0)$ is the failure probability.

If the random stress $\sigma_{B}$ and allowable strength $\sigma_{a}$ are normally distributed respectively with the mean values and standardized deviations $\left(\bar{\sigma}_{B}, S_{B}\right)\left(\bar{\sigma}_{a}, S_{a}\right)$, the probability density function of a normal distributed stress can be determined as follows:

$$
f_{B}\left(\sigma_{B}\right)=\frac{1}{S_{B} \sqrt{2 \pi}} e^{-\left[\frac{\left(\sigma_{B}-\bar{\sigma}_{B}\right)^{2}}{2 S_{B}^{2}}\right]}
$$

Similarly, the probability density function of the allowable strength can be determined. The random variable $U$ is, likewise, normally distributed. The unreliability for the interference area of the two distributions can be calculated using the following equation:

$$
Z=\frac{\bar{\sigma}_{a}-\bar{\sigma}_{B}}{\sqrt{S_{a}^{2}+S_{B}^{2}}}
$$

Then, the reliability can be simply calculated as follows:

$$
R=\Phi\left(\frac{\bar{\sigma}_{a}-\bar{\sigma}_{B}}{\sqrt{S_{a}^{2}+S_{B}^{2}}}\right)
$$

\subsection{Reliability calculation based on gear bending fatigue}

The bending stress of the gear root is the biggest stress in gear transmission process under the alternating bending stress, and the tooth is easy to produce fatigue crack and crack expansion under the alternating bending stress which will lead to tooth bending fatigue fracture. The bending stress can be calculated by $[9,15,16]$ :

$$
\sigma_{F}=Y_{F a} Y_{S a} Y_{\varepsilon} Y_{\beta} \frac{F_{t}}{b m_{n}} K_{A} K_{V} K_{F \beta} K_{F a}
$$

where $m_{n}$ is the normal module, $Y_{F a}$ is the tooth form factor, $Y_{S a}$ is the bending stress concentration coefficient, $Y_{\varepsilon}$ is the contact ratio factor, $Y_{\beta}$ is the helix angle coefficient, $F_{t}$ is the rated tangential tooth force at transverse pitch, $b$ is the active face width, $K_{A}$ is the work condition coefficient, $K_{V}$ is the dynamic load coefficient, $K_{F a}$ is the load distribution coefficient, $K_{F \beta}$ is the longitudinal load distribution coefficient.

The tooth bending fatigue strength is defined as:

$$
\sigma_{\text {Flim }}^{\prime}=\sigma_{\text {Flim }} Y_{S T} Y_{N T} Y_{\text {srelt }} Y_{\text {Rrelt }} Y_{X}
$$

where $\sigma_{\text {Flim }}$ is the experimental gear bending fatigue strength, $Y_{S T}$ is the experimental gear tooth stress concentration coefficient, $Y_{N T}$ is the life coefficient, $Y_{\text {srelt }}$ is the relative sensitive coefficient, $Y_{\text {Rrelt }}$ is the relative surface condition coefficient, $Y_{X}$ is the size coefficient.

According to the stress-strength interference theory, the limit state function of bending fatigue is defined as:

$$
f(\sigma)=\ln \left(\sigma_{F l i m}^{\prime}\right)-\ln \left(\sigma_{F}\right)
$$

According to the Eq. (8), the mean of function can be calculated as:

$$
\begin{aligned}
E[f(\sigma)] & =E\left[\ln \left(\sigma_{\text {Flim }}^{\prime}\right)\right]-E\left[\ln \left(\sigma_{F}\right)\right] \\
& =E\left[\ln \left(\frac{\sigma_{\text {Flim }}^{\prime}}{\sigma_{F}}\right)\right]
\end{aligned}
$$

where:

$$
E\left[\ln \left(\sigma_{\text {Flim }}^{\prime}\right)\right]=\ln \left[E\left(\sigma_{\text {Flim }}\right) E\left(\mathrm{Y}_{S T}\right) E\left(\mathrm{Y}_{N T}\right) E\left(\mathrm{Y}_{\text {srelt }}\right) E\left(\mathrm{Y}_{\text {Rrelt }}\right) E\left(\mathrm{Y}_{X}\right)\right]
$$

$E\left[\ln \left(\sigma_{F}\right)\right]=\ln \left[E\left(\mathrm{Y}_{F a}\right) E\left(\mathrm{Y}_{S a}\right) E\left(\mathrm{Y}_{\varepsilon}\right) E\left(\mathrm{Y}_{\beta}\right) \frac{E\left(F_{t}\right)}{E(b) E\left(m_{n}\right)} E\left(K_{A}\right) E\left(K_{V}\right) E\left(K_{F \beta}\right) E\left(K_{F a}\right)\right.$

The variance of the function is as follow:

$$
D[f(\sigma)]=D\left[\ln \left(\sigma_{F l i m}^{\prime}\right)\right]+D\left[\ln \left(\sigma_{F}\right)\right]
$$

Supposed the random variable $x$ is normally distributed, the variance of function $y=\ln (x)$ is:

$$
\sigma^{2}(y)=\left[\left.\frac{d y}{d x}\right|_{E(x)} \sigma(x)\right]^{2}=\left[\frac{\sigma(x)}{E(x)}\right]^{2}=C^{2}(x)
$$

For multivariable function $y$ composed of multiple independent random variables, the expression is:

$$
y=a x_{1}^{m_{1}} x_{2}^{m_{2}} \ldots x_{n}^{m_{n}}=a \prod_{i=1}^{n} x_{i}^{m_{i}}
$$

$x_{1}, x_{2}, \cdots, x_{n}$ is independent random variables. 
According to Eqs. (13) and (14), the variable coefficient of $y$ using the first order Taylor expansion can be expressed as:

$$
C_{y}^{2}=\sum_{i=1}^{n} m_{i}^{2} C_{x_{i}}^{2}
$$

According to Eq. (12), we have:

$$
D[f(\sigma)]=C^{2}\left(\sigma_{F l i m}^{\prime}\right)+C^{2}\left(\sigma_{F}\right)
$$

According to Eqs. (6), (15), and (16), the variable coefficient of $\sigma_{F \lim }^{\prime}$ and $\sigma_{F}$ can be respectively expressed as:

$C^{2}\left(\sigma_{F}\right)=C_{Y_{F a}}^{2}+C_{Y_{S a}}^{2}+C_{Y_{e}}^{2}+C_{Y_{b}}^{2}+C_{F_{t}}^{2}+C_{b}^{2}+C_{m_{n}}^{2}+C_{K_{A}}^{2}+C_{K_{V}}^{2}+C_{K_{F \beta}}^{2}+C_{K_{F a}}^{2}$

$$
C^{2}\left(\sigma_{\text {Flim }}^{\prime}\right)=C_{\sigma_{F l i m}}^{2}+C_{Y_{S T}}^{2}+C_{Y_{N T}}^{2}+C_{Y_{\text {srelt }}}^{2}+C_{Y_{\text {Rrelt }}}^{2}+C_{Y_{X}}^{2}
$$

Substituting Eqs. (11) and (17) into the reliability formula, the reliability index for gear bending fatigue strength can be given by:

$$
\beta_{F}=\frac{E\left(f_{\sigma}\right)}{\sigma\left(f_{\sigma}\right)}=\frac{E\left[\ln \left(\frac{\sigma_{F l i m}^{\prime}}{\sigma_{F}}\right)\right]}{\sqrt{C^{2}\left(\sigma_{F l i m}^{\prime}\right)+C^{2}\left(\sigma_{F}\right)}}
$$

Reliability for gear bending fatigue strength is:

$$
R=\Phi\left(\beta_{F}\right)
$$

\subsection{Reliability design based on contact fatigue}

The fatigue life of gears has been studied over many years, and the gear contact fatigue performance is very important from the former studies. Gear tooth contact fatigue is a key characteristic of the gear and affected by design geometry, material, manufacturing methods and other variables. Surface contact fatigue is the common cause of gear failure. It results in damage to the contacting surfaces which can significantly reduce the load-carrying capacity of components, and may ultimately lead to the complete failure of a gear.

Gear contact stress is defined as [16, 17]:

$$
\sigma_{H}=Z_{H} Z_{E} Z_{e} Z_{B} \sqrt{\frac{F_{t}}{b d_{1}} \frac{u+1}{u} K_{A} K_{V} K_{H \beta} K_{H A}}
$$

where $F_{t}$ is the rated tangential tooth force at transverse pitch, $b$ is the active face width, $K_{A}$ is the work condition coefficient, $K_{V}$ is the dynamic load coefficient, $K_{H \beta}$ is the longitudinal load distribution coefficient, $K_{H A}$ is the transverse load distribution coefficient, $Z_{H}$ is the nodal field coefficient, $Z_{E}$ is the elastic coefficient, $Z_{e}$ is the contact ratio coefficient, $Z_{B}$ is the spiral angle coefficient, $d_{1}$ is the pinion pitch diameter, $u$ is the gear ratio.

Contact fatigue strength of tooth faces is defined as:

$$
\sigma_{\text {Hlim }}^{\prime}=\sigma_{H l i m} Z_{N} Z_{R} Z_{V} Z_{L} Z_{W} Z_{X}
$$

where $\sigma_{H l i m}$ is the experimental flank contact fatigue strength, $Z_{N}$ is the life coefficient, $Z_{R}$ is the tooth fineness coefficient, $Z_{V}$ is the velocity coefficient, $Z_{L}$ is the lubricant coefficient, $Z_{W}$ is the work harden coefficient, $Z_{X}$ is the size coefficient.

According to stress-strength interference theory, the limit state function is defined as:

$$
g(\sigma)=\ln \left(\sigma_{H l i m}^{\prime}\right)-\ln \left(\sigma_{H}\right)
$$

According to Eq. (23), the mean of the function is calculated as:

$$
\begin{aligned}
E[g(\sigma)] & =E\left[\ln \left(\sigma_{H l i m}^{\prime}\right)\right]-E\left[\ln \left(\sigma_{H}\right)\right] \\
& =E\left[\frac{\ln \left(\sigma_{H l i m}^{\prime}\right)}{\ln \left(\sigma_{H}\right)}\right]
\end{aligned}
$$

where:

$$
E\left[\ln \left(\sigma_{\text {Hlim }}^{\prime}\right)\right]=\ln \left[E\left(\sigma_{H l i m}\right) E\left(Z_{N}\right) E\left(Z_{R}\right) E\left(Z_{V}\right) E\left(Z_{L}\right) E\left(Z_{W}\right) E\left(Z_{X}\right)\right]
$$

$$
E\left[\ln \left(\sigma_{H l i m}\right)\right]=\ln \left[\sqrt{\frac{u \pm 1}{u}} E\left(Z_{H}\right) E\left(Z_{E}\right) E\left(Z_{e}\right) E\left(Z_{B}\right) \sqrt{\frac{E\left(F_{t}\right)}{E\left(b d_{1}\right) E\left(d_{1}\right)} E\left(K_{A}\right) E\left(K_{V}\right) E\left(K_{H \beta}\right) E\left(K_{H A}\right)}\right]
$$

The variances of the function is:

$$
\begin{aligned}
D[g(\sigma)] & =D\left[\ln \left(\sigma_{H l i m}^{\prime}\right)\right]+D\left[\ln \left(\sigma_{H}\right)\right] \\
& =C^{2}\left[\ln \left(\sigma_{H l i m}^{\prime}\right)\right]+C^{2}\left[\ln \left(\sigma_{H}\right)\right]
\end{aligned}
$$
by:

The variable coefficients of $\sigma_{H \text { lim }}^{\prime}$ and $\sigma_{H}$ are respectively given

$$
\begin{gathered}
C^{2}\left(\sigma_{\text {Hlim }}^{\prime}\right)=C_{\sigma_{H l i m}}^{2}+C_{Z_{N}}^{2}+C_{Z_{R}}^{2}+C_{Z_{V}}^{2}+C_{Z_{L}}^{2}+C_{Z_{W}}^{2}+C_{Z_{X}}^{2} \\
C^{2}\left(\sigma_{H \text { Him }}\right)=C_{Z_{H}}^{2}+C_{Z_{E}}^{2}+C_{Z_{e}}^{2}+C_{Z_{B}}^{2}+\frac{1}{4}\left(C_{F_{t}}^{2}+C_{K_{A}}^{2}+C_{K_{V}}^{2}+C_{K_{H \beta}}^{2}+C_{K_{H A}}^{2}\right)
\end{gathered}
$$

Substituting Eqs. (26) and (27) into the reliability formula, the reliability index for gear contact fatigue strength can be calculated as:

$$
\beta_{H}=\frac{E\left(g_{H}\right)}{\sigma\left(g_{H}\right)}=\frac{E\left[\frac{\ln \left(\sigma_{H l i m}^{\prime}\right)}{\ln \left(\sigma_{H}\right)}\right]}{\sqrt{C^{2}\left[\ln \left(\sigma_{H l i m}^{\prime}\right)\right]+C^{2}\left[\ln \left(\sigma_{H}\right)\right]}}
$$

Reliability for gear contact fatigue strength is:

$$
R=\Phi\left(\beta_{H}\right)
$$

\subsection{Reliability design based on flank adhesion}

Generally, we should consider not only contact fatigue strength and bending fatigue strength, but also the scuffing failure during the design of a high speed heavy gear. Flank adhesion damage occurs on gear teeth if they are operated with an inadequate lubricant film 
between the teeth. High surface temperatures then arise from the frictional heating, local welding and surface dragging as well as scoring therefore tend to occur. Because flank adhesion failure usually occurs in the sudden onset of high-speed heavy conditions, thereby limiting load capacity and the service life $[3,5,6,17]$.

According to GB/Z 6413, tooth of gear integral temperature $\theta_{S}$ is:

$\theta_{S}=\theta_{M}+1.5 \times\left\{0.12 \frac{F_{t}}{b} K_{A} K_{B} K_{B \beta} K_{B \gamma}\left(\frac{1}{v_{\Sigma} \eta_{a i l}}\right)^{0.25}\left(\frac{R_{a 1}+R_{a 2}}{2 Q_{r e d c}}\right)^{0.25} X_{M} X_{B E} X_{\alpha \beta} \frac{K_{B \gamma}^{0.75} v^{0.5}}{|a|^{0.25}} \frac{1}{X_{Q} X_{C a}} X_{\varepsilon}\right\}$

\section{Reliability analysis of gears considering failure cor- relation}

Generally, when component has multiple failure modes, the occurrence of any kind of failure mode will lead to component failure [12]. As a result, reliability of component with multiple failure modes can be regarded as a series system, as shown in Fig.1.

It was generally considered that the parts and failure modes of mechanical system are mutually independent. Therefore reliability of a series system is: where $\theta_{M}$ is the body temperature, $K_{B \gamma}$ is the twist coefficient of abrasion, $X_{M}$ is the coefficient of thermal expansion, $X_{B E}$ is the addendum coefficient, $X_{\alpha \beta}$ is the coefficient of pressure angle, $X_{Q}$ is the contact ratio, $X_{C a}$ is the addendum modification coefficient, $X_{\varepsilon}$ is the scuffing calculate contact ratio factor, $R_{a 1}, R_{a 2}$ are the arithmetic average roughness values.

The scuffing temperature limit is defined as:

$$
\theta_{B}=\theta_{M}+1.5 \theta_{\text {flaint }}
$$

where $\theta_{\text {flaint }}$ is flash temperature.

According to the stress-strength interference theory, the limit state function is defined as:

$$
g_{S}=\theta_{B}-\theta_{S}
$$

According to Eq. (23), the mean and variable of the function are as follows:

$$
\begin{gathered}
E\left(g_{S}\right)=E\left(\theta_{B}\right)-E\left(\theta_{S}\right) \\
D\left(\theta_{\text {int }}\right)=D\left(\theta_{M}\right)+1.5^{2} D\left(\theta_{\text {fla int }}\right) \\
=C_{\theta_{M}}^{2} E^{2}\left(\theta_{M}\right)+1.5^{2} C\left(\theta_{\text {fla int }}\right) E^{2}\left(\theta_{\text {fla int }}\right)
\end{gathered}
$$

where:

$C_{\theta_{f l a i n t}}=\sqrt{C_{F_{t}}^{2}+C_{K_{A}}^{2}+C_{K_{B}}^{2}+C_{K_{B \beta}}^{2}+C_{K_{B \gamma}}^{2}+C_{X_{M}}^{2}+C_{X_{B E}}^{2}+C_{X_{\alpha \beta}}^{2}+C_{X_{\varepsilon}}^{2}}$

The reliability index for gear flank adhesion can be calculated as:

$$
\begin{aligned}
& \beta_{\theta}=\frac{E\left(g_{S}\right)}{\sigma\left(g_{S}\right)}=\frac{E\left(g_{S}\right)}{\sqrt{D\left(g_{S}\right)}} \\
& =\frac{E\left(\theta_{\text {int } s}\right)-E\left(\theta_{\text {int }}\right)}{\sqrt{D\left(\theta_{\text {int } s}\right)+D\left(\theta_{\text {int }}\right)}}
\end{aligned}
$$

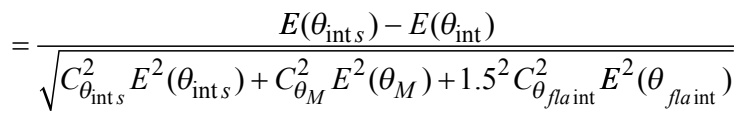

Reliability of the flank adhesion is:

$$
R=\Phi\left(\beta_{\theta}\right)
$$

$$
R_{S}(t)=R_{1} R_{2} \cdots R_{n}=\prod_{i=1}^{n} R_{i}(t)
$$

where $R_{S}(t)$ is reliability of the system, $R_{i}$ is reliability of the $i$ th failure mode.

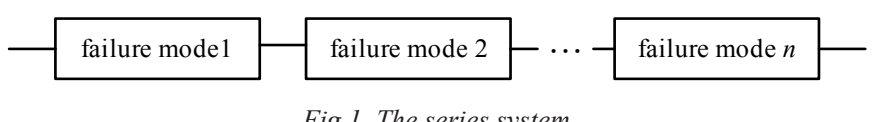

In practices, for the most engineering systems, their parts work in the same random load environment, and thus their failures are not mutually independent. Correlation is an inherent specialty of complicated mechanical systems, which is one of the greatest issues affecting and restricting mechanical reliability research $[2,6,7,10]$. If the dependence of system failures is ignored, analysis of system reliability often leads to an excessive error. When we consider the correlation of mechanical components with multiple failure modes, reliability can be shown as:

$$
\begin{aligned}
R(t)= & P\left\{\min \left(T_{1}, T_{2}, \cdots, T_{n}\right)>t\right\}=P\left(T_{1}>t, T_{2}>t, \cdots, T_{n}>t\right) \\
= & 1-\sum_{i=1}^{n} P\left(T_{i} \leq t\right)+\sum_{1 \leq i<j \leq n}^{n} P\left(T_{i} \leq t, T_{j} \leq t\right)+\cdots+(-1)^{k} \times \\
& \sum_{1 \leq i_{1}<i_{2}<\cdots i_{k} \leq n}^{n} P\left(T_{i_{1}} \leq t, T_{i_{2}} \leq t, \cdots, T_{i_{k}} \leq t\right)+\cdots+(-1)^{k} P\left(T_{i_{1}} \leq t, T_{i_{2}} \leq t, \cdots, T_{i_{k}} \leq t\right) \\
= & 1-\sum_{i=1}^{n} F_{i}(t)+(-1)^{k} \times \sum_{1 \leq i_{1}<i_{2}<\cdots<i_{k} \leq n}^{n} C\left(F_{i_{1}}(t), F_{i_{2}}(t), \cdots, F_{i_{n}}(t)\right)
\end{aligned}
$$

where $F_{i}(t)$ is a failure probability. $C\left(F_{i_{1}}(t), F_{i_{2}}(t), \cdots, F_{i_{n}}(t)\right)$ is a copula function. As a useful tool to establish a joint distribution function from its marginal distributions, copula functions are often adopted to study correlation problems. Copulas provide a way of specifying joint distributions if only the marginal distributions are known. In terms of reliability problem with multiple failure modes, we can obtain a multivariate distribution for modeling joint behavior of failure modes using the marginal distributions of each failure mode and the copula function $[7,9,16,17]$.

Let $F_{X}(x)$ and $F_{Y}(y)$ denote the marginal distribution functions of variables $X$ and $Y$, respectively. The joint distribution function $F_{X, Y}(x, y)$ can be expressed as:

$$
F_{X, Y}(x, y)=C\left[F_{X}(x), F_{Y}(y)\right]
$$

where $C(u, v)$ is the copula function. 
If $F_{X}(x)$ and $F_{Y}(y)$ are continuous functions, $C(u, v)$ is unique. Since $F_{X}(x)$ and $F_{X}(x)$ are univariate functions and $C(u, v)$ is a copula function, then $F_{X, Y}(x, y)$ is a bivariate joint distribution function with marginal $F_{X}(x)$ and $F_{Y}(y)$.

Generally, the Archimedean copula functions are often adopted to build the joint distribution function. An N-dimensional Archimedean copula is given by:

$$
C\left(u_{1}, u_{2}, \cdots, u_{N}\right)=\varphi\left(\varphi^{-1}\left(u_{1}\right), \varphi^{-1}\left(u_{2}\right), \cdots, \varphi^{-1}\left(u_{N}\right)\right)
$$

where $\varphi$ is the generator.

One of the important natural properties of the Archimedean copulas can be represented by the following expression,

$$
\begin{gathered}
C\left(u_{1}, u_{2}, u_{3}\right)=C\left[C\left(u_{1}, u_{2}\right), u_{3}\right] \\
C\left(u_{1}, u_{2}, u_{3}, u_{4}\right)=C\left[C\left(u_{1}, u_{2}, u_{3}\right), u_{4}\right] \\
C\left(u_{1}, u_{2}, \cdots, u_{N-1}, u_{N}\right)=C\left[C\left(u_{1}, u_{2}, \cdots, u_{N-1}\right), u_{N}\right]
\end{gathered}
$$

Eqs. (44-46) show that any N-dimensional Archimedean copula could be deduced by a two-dimension copula. In terms of mechanical parts, the failure modes are generally positive correlated, and the joint distribution function could be built by the Gumbel copula function. The expression of the Gumbel copula is as follows $[10,11,14]$ :

$$
C_{G}(u, v ; \theta)=\exp \left\{-\left[(-\ln u)^{\frac{1}{\theta}}+(-\ln v)^{\frac{1}{\theta}}\right]^{\theta}\right\} \quad \theta \in(0,1)
$$

\section{Numerical example}

In this section, we use the proposed method to calculate reliability of a gear transmission for a heavy machine tool. The material of gear is $18 \mathrm{Cr} 2 \mathrm{Ni} 4 \mathrm{WA}$. In accordance to the standard regulations or looking up in figures $[13,15,16,17]$, we get the mean values of each parameter of gear pairs, and the standard deviation of each parameter based on the aforementioned principles. The variable coefficients are shown in Table 1.

According to Table 1 , the reliability index $\beta_{i}$, reliability $R_{i}$ of each failure mode for gear are obtained, shown in Table 2 .

According to Table 2, the major failure modes for gear are sorted as bending fatigue failure, flank adhesion failure and contact fatigue failure. Gear bending fatigue is a major failure mode. The more operating torque increases, the more gear bending fatigue strength will be. Therefore, gear tooth bending fatigue is a key characteristic of the gear and affected by geometry, material, manufacturing methods and other variables.

Using Eq. (35), according to the assumption of mutually independent, the reliability of the driving gear and driven gear respecti-

\begin{tabular}{|c|c|c|c|}
\hline variable & variable coefficient & variable & variable coefficient \\
\hline$F_{t}$ & $C_{F_{t}}=659.66$ & $X_{Q}$ & $C_{X_{Q}}=0.03$ \\
\hline$Y_{F a 1}$ & $C_{Y_{F a 1}}=0.778$ & $X_{B E}$ & $C_{X_{B E}}=0.03$ \\
\hline$Y_{F a 2}$ & $C_{Y_{F a 2}}=0.0703$ & $Z_{\varepsilon}$ & $C_{Z_{\varepsilon}}=0.045$ \\
\hline$Y_{S a 1}$ & $C_{Y_{S a 1}}=0.0577$ & $Z_{\beta}$ & $C_{Z_{\beta}}=0.0478$ \\
\hline$Y_{S a 2}$ & $C_{Y_{S a 2}}=0.0706$ & $Z_{F}$ & $C_{Z_{F}}=0.02$ \\
\hline$Y_{\varepsilon}$ & $C_{Y_{\varepsilon}}=0.0357$ & $Z_{N}$ & $C_{Z_{N}}=0.03$ \\
\hline$Y_{\beta}$ & $C_{Y_{\beta}}=0.004$ & $Z_{R}$ & $C_{Z_{R}}=0.036$ \\
\hline$Y_{S T}$ & $C_{Y_{S T}}=0.0693$ & $Z_{V}$ & $C_{Z_{V}}=0.033$ \\
\hline$Y_{N T}$ & $C_{Y_{N T}}=0.033$ & $Z_{L}$ & $C_{Z_{L}}=0.033$ \\
\hline$Y_{\sigma r e l t 1}$ & $C_{Y_{\sigma \text { relt } 1}}=0.033$ & $Z_{W}$ & $C_{Z_{W}}=0.037$ \\
\hline$Y_{\sigma \text { relt } 2}$ & $C_{Y_{\sigma \text { relt } 2}}=0.033$ & $Z_{E}$ & $C_{Z_{E}}=0.033$ \\
\hline$Y_{\text {Rrelt } 1}$ & $C_{Y_{\text {Rrelt } 1}}=0.0351$ & $Z_{X}$ & $C_{Z_{X}}=0.033$ \\
\hline$Y_{\text {Rrelt } 2}$ & $C_{\text {Rrelt } 2}=0.0351$ & $Z_{H}$ & $C_{Z_{H}}=0.116$ \\
\hline$Y_{X}$ & $C_{Y_{X}}=0.0451$ & $\theta_{M}$ & $C_{\theta_{M}}=0.03$ \\
\hline$K_{A}$ & $C_{K_{A}}=0.033$ & $\theta_{\text {ints }}$ & $C_{\theta_{\text {ints }}}=0.03$ \\
\hline$K_{V}$ & $C_{K_{V}}=0.033$ & $\sigma_{H \lim }$ & $C_{\sigma_{H \lim }}=0.06$ \\
\hline$K_{H \beta}$ & $C_{K_{H \beta}}=0.055$ & $X_{\alpha \beta}$ & $C_{X_{\alpha \beta}}=0.032$ \\
\hline$K_{H \alpha}$ & $C_{K_{\mathrm{H} \alpha}}=0.0382$ & $X_{M}$ & $C_{X_{M}}=0.027$ \\
\hline$K_{F \alpha}$ & $C_{K_{F \alpha}}=0.0382$ & $X_{C a}$ & $C_{X_{C a}}=0.03$ \\
\hline
\end{tabular}
vely are:

$$
\begin{gathered}
R_{1}=R_{F_{1}} R_{H_{1}} R_{\theta_{1}}=0.9659 \\
R_{2}=R_{F_{2}} R_{H_{2}} R_{\theta_{2}}=0.9748
\end{gathered}
$$

Reliability of gear pair is $R=R_{1} R_{2}=0.94159$.
Table 1. The variable coefficient of gear

Table 2. The index reliability and the reliability for gear

\begin{tabular}{cccc}
\hline & \multicolumn{2}{c}{$\beta_{i}$} & $R_{i}=\Phi\left(\beta_{i}\right)$ \\
\hline \multirow{2}{*}{$\begin{array}{c}\text { gear bending fatigue } \\
\text { failure }\end{array}$} & driving gear & 2.02 & $R_{F_{1}}=0.9783$ \\
\cline { 2 - 4 } & driven gear & 2.15 & $R_{F_{2}}=0.9838$ \\
\hline $\begin{array}{c}\text { gear contact fatigue } \\
\text { failure }\end{array}$ & driving gear & 3.5 & $R_{H_{1}}=0.9935$ \\
\cline { 2 - 4 } & driven gear & 2.8 & $R_{H_{2}}=0.9974$ \\
\hline $\begin{array}{c}\text { gear flank adhesion } \\
\text { failure }\end{array}$ & driving gear & 2.5 & $R_{\theta_{1}}=0.9938$ \\
\cline { 2 - 4 } & driven gear & 3.2 & $R_{\theta_{2}}=0.993$ \\
\hline \hline
\end{tabular}


The results obtained by Monte Carlo simulation are

$R_{1 M C S}=0.9878, R_{2 M C S}=0.9762, R_{M C S}=0.9754$.

where $R_{1 M C S}$ is reliability of a driving gear, $R_{2 M C S}$ is reliability of a driving gear, $R_{M C S}$ is the reliability of gear pair. All the results are calculated using Monte Carlo simulation.

The relative error is:

$$
\varepsilon=\left|R-R_{M C S}\right| / R_{M C S}=3.4 \%
$$

According to the properties of the Gumbel copula $C\left(P_{i}, P_{h}\right)$ $(1 \leq i, h \leq 3)$, the $C\left(P_{i}, P_{h}, P_{t}\right) \quad(1 \leq i<h<t \leq 3) \quad$ can be obtained:

$$
\begin{gathered}
C\left(P_{1 F}, P_{1 H}\right)=0.2412 \\
C\left(P_{1 F}, P_{1 \theta}\right)=0.1262 \\
C\left(P_{1 H}, P_{1 \theta}\right)=0.0978 \\
C\left(P_{2 F}, P_{2 H}\right)=0.1348 \\
C\left(P_{2 F}, P_{2 \theta}\right)=0.0723 \\
C\left(P_{2 H}, P_{2 \theta}\right)=0.1527 \\
C\left(P_{1 H}, P_{1 F}, P_{1 \theta}\right)=C\left(C\left(P_{1 H}, P_{1 F}\right), P_{1 \theta}\right)=0.045 \\
C\left(P_{2 H}, P_{2 F}, P_{2 \theta}\right)=C\left(C\left(P_{2 H}, P_{2 F}\right), P_{2 \theta}\right)=0.032 \\
C\left(P_{1}, P_{2}\right)=0.1264
\end{gathered}
$$

According to Copula theory, reliability of the driving gear and driven gear can be respectively given by:

$$
\begin{aligned}
& R_{1}^{\prime}=0.9867 \\
& R_{2}^{\prime}=0.9884
\end{aligned}
$$

Reliability of the gear pair is $R^{\prime}=0.9851$. The relative error is $\varepsilon=\left|R^{\prime}-R_{M C S}\right| / R_{M C S}=0.94 \%$.

From aforementioned results, we know that the relative error for mutually independent of failure modes is greater than considers failure correlation. Since this paper only considers three main failure modes, so the difference of relative error is not obvious. When we consider multiple failure modes, the proposed method is superior to traditional methods without considering correlations.

\section{Conclusions}

This paper has established reliability model with three major failure modes: tooth bending fatigue, gear contact fatigue and gear scuffing failure. From the reliability calculation model, it is concluded that the primary failure mode of gear is the tooth surface contact fatigue failure and secondary failure mode is the gear scuffing failure. Based the copula theory, a reliability calculation method of the gear under considering correlation for multiple failure modes are developed. A comparative analysis has shown that the accuracy and practicality of the proposed model is higher than the model without consider failure correlation. However, correlations widely exist in practical engineering. Therefore, this method provides an effective and reliable approach to assess reliability of engineering systems.

\section{Acknowledgment}

This research was supported by the National Science and Technology Major Project of China under the contract number 2013ZX04013011, and the National Natural Science Foundation of China under contract number 11272082.

\section{References}

1. Al-Shareedah E M, Alawi H. Reliability analysis of bevel gears with and without back support. Mechanism \& Machine Theory 1987; 22(1): 13-20, http://dx.doi.org/10.1016/0094-114X(87)90071-1.

2. Aoues Y, Chateauneuf A. Benchmark study of numerical methods for reliability-based design optimization. Structural and Multidisciplinary Optimization 2010; 41: 277-294, http://dx.doi.org/10.1007/s00158-009-0412-2.

3. Krantz T, Tufts B. Pitting and bending fatigue evaluations of a new case-carburized gear steel. International Design Engineering Technical Conferences and Computers and Information in Engineering Conference 2007; 4-7, http://dx.doi.org/10.1115/detc2007-34090.

4. Lyu S K, Inoue K, Deng G, et al. Effect of surface treatments on the strength of carburized gears. KSME International Journal 1998; 12(2): 206-214.

5. Li Y F, Mi J, Huang H Z, et al. Fault tree analysis of train rear-end collision accident considering common cause failure. Ekcsploatacja i Niezawodnosc - Maintenance and Reliability 2013; 15(4): 403-408.

6. Madhusekhar D. Reliability based design of a gear box. Journal of Engineering Research and Applications 2009; 4(8): 38-44.

7. Nelsen R B. An introduction to Copulas. Springer Verlag, 2006; 27-32.

8. Noh Y, Choi K, Du L. Reliability-based design optimization of problems with correlated input variables using a Gaussian copula. Structural and Multidisciplinary Optimization 2009; 38(1): 1-16, http://dx.doi.org/10.1007/s00158-008-0277-9.

9. Peng X Q, Liu G, Wu L Y, et al. A stochastic finite element method for fatigue reliability analysis of gear teeth subjected to bending. Computational Mechanics 1998; 21: 253-261, http://dx.doi.org/10.1007/s004660050300.

10. Ramirez-Marquez J E, Coit D W. Optimization of system reliability in the presence of common cause failures. Reliability Engineering and System Safety 2007; 92: 1421-1434, http://dx.doi.org/10.1016/j.ress.2006.09.004.

11. Rao S S, Das G. Reliability based optimum design of gear trains. Journal of Mechanical Design 1984; 106(1): 17-22, http://dx.doi. org/10.1115/1.3258551.

12. Xiao N C, Huang H Z, Li Y F, et al. Multiple failure modes analysis and weighted risk priority number evaluation in FMEA. Engineering Failure Analysis 2011; 18(4): 1162-1170, http://dx.doi.org/10.1016/j.engfailanal.2011.02.004.

13. Yang Q J. Fatigue test and reliability design of gears. International Journal of Fatigue 1996; 18(3): 71-177, http://dx.doi.org/10.1016/01421123(95)00096-8.

14. Ye X F, Wang Q, Huang Z Y. Research on probabilistic reliability design of gears. Locomotive \& Rolling Stock Technology 2011; 3: 1-5. (In Chinese). 
15. Zhang J, Zhang Q, Xu Z Z, et al. A study on the evaluation of bending fatigue strength for $20 \mathrm{CrMoH}$ gear. International Journal of Precision Engineering and Manufacturing 2013; 14(8): 1339-1343, http://dx.doi.org/10.1007/s12541-013-0181-0.

16. Zhang Q, Zhang J, Wu C. The evaluation of contact fatigue strength for $20 \mathrm{MnCr} 5$ carburized gear. International Journal of Precision Engineering and Manufacturing 2014; 15(1): 117-121, http://dx.doi.org/10.1007/s12541-013-0313-6.

17. Zhang Y M, Liu Q L, Wen B C. Practical reliability-based design of gear pairs. Mechanism and Machine Theory 2003; 38(12): 1363-1370, http://dx.doi.org/10.1016/S0094-114X(03)00092-2.

\section{Fang-Jun ZUO \\ Le YU \\ Jinhua MI \\ Zheng LIU \\ Hong-Zhong HUANG}

Institute of Reliability Engineering

University of Electronic Science and Technology of China

No. 2006, Xiyuan Avenue, West Hi-Tech Zone, Chengdu,

Sichuan, 611731, P. R. China

E-mails: hzhuang@uestc.edu.cn 